\title{
Studies on dairy production of milking ewes I. - Estimates of genetic parameters for total milk composition and yield
}

\author{
F. BARILLET and D. BOICHARD ${ }^{(*)}$ \\ I.N.R.A., Station d'Amélioration Génétique des Animaux, \\ Toulouse, BP 27, F 31326 Castanet-Tolosan \\ (*) I.N.R.A., Station de Génétique quantitative et appliquée, F 78350 Jouy-en-Josas
}

\begin{abstract}
Summary
Genetic parameters for dairy traits in first lactation (milk yield, fat and protein yields, fat and protein contents) were estimated from records of 1487 Lacaune ewe lambs born from 102 young rams undergoing progeny test and 74 proven rams. Variance and covariance components were estimated by HeNDERSON's methods I and III. According to the analysis, information from proven rams was totally or partially used for estimating fixed effects, or was excluded. Results appeared similar to the average literature data for dairy cows, except the correlation between fat and protein contents, which was rather high $(0.8)$. The genetic standard deviation of fat was larger than that of protein, the ratio being about 1.3 for yields and 1.85 for contents. Accordingly, expected genetic change is likely to be smaller for protein matter than for fat matter. Whereas the genetic correlation between fat content and yield was positive, the genetic correlations between protein content and yield, or between content of one component and yield of the other, seemed to be close to zero and maybe negative. Accordingly, the selection criterion should include useful yield and content, instead of the useful yield alone. Useful yield (or content) was defined as a combination of fat and protein yields (or contents), with weighting 1 and 1.85 respectively.
\end{abstract}

Key words : Dairy ewes, milk composition, milk yield, genetic parameters, selection goal.

\section{Résumé \\ Etudes sur la production laitière des brebis traites \\ 1. - Paramètres génétiques de la quantité et composition totale du lait à la traite}

Les paramètres génétiques des caractères laitiers (quantité de lait, de matière grasse et de matière protéique, taux butyreux et protéique) sont estimés à partir d'un fichier de 1487 agnelles de race Lacaune en $1^{\text {re }}$ lactation, issues de 102 béliers de testage et 74 mâles de service. Ils sont estimés par décomposition de la variance et de la covariance entre demi-sœurs de père, en appliquant les méthodes I ou III d'Henderson, aux données de testage. L'information des pères de service est utilisée en totalité, partiellement, ou ignorée, pour estimer les effets fixés. Les résultats obtenus selon ces 3 analyses sont cohérents entre eux, et globalement conformes à la moyenne bibliographique connue en vache laitière, à l'exception de la corrélation génétique entre les taux butyreux et protéique qui ici apparaît plus élevée $(0,8)$. La matière grasse est plus variable que la matière protéique, puisque le rapport des écarts-types génétiques est estimé à 1,3 pour les quantités et à 1,85 pour les taux. Les possibilités d'évolution génétique de la matière grasse sont donc plus importantes que celles de la matière protéique. Alors que la corrélation génétique entre le taux butyreux et la quantité de matière grasse est positive, les corrélations génétiques entre le 
taux protéique et sa matière, ou entre un taux et la quantité de l'autre matière, sont proches de zéro, et peut-être négatives. Il est conseillé en conséquence de sélectionner sur une combinaison linéaire de la quantité et du taux moyen de matière utile, plutôt que sur la matière utile seule. Les critères "quantité ou taux moyen de matière utile " sont eux-mêmes définis comme une combinaison des quantités (ou taux) de matière grasse et protéique, avec des pondérations économiques égales respectivement à 1 et 1,85 .

Mots clés : Brebis laitières, composition du lait, quantité de lait, paramètres génétiques, objectif de sélection.

\section{Introduction}

Since the 1960's the main selection goal for dairy ewes was limited to the milk yield. Two reasons motivated this choice. On the one hand, the low level of milk production with a high concentration necessitated the fast development of a selection scheme. On the other hand, recording the milk concentration on the farm was not economically feasible within the usual type A procedure, i.e. two measurements a day once a month.

Nowadays the selection scheme applied to the whole Lacaune population is producing a continual improvement in milk yield (BARILlet et al., 1986). The selection program may now be reexamined in order to take into account the milk composition, since sheep milk is exclusively processed into cheese. That question involves three steps : a new definition of the main selection criterion, the design of a simplified recording procedure for milk composition, suited to the species at a reasonable cost, and the integration of that procedure in the selection scheme. The genetic parameters for yields and milk composition are to be estimated first, especially since the literature on that topic is very scarce for the dairy ewes. In order to achieve that aim, a qualitative dairy recording procedure of type A (two milkings a month) has been experimentally set up on 6798 ewes of the Lacaune selection nucleus between 1979 and 1981 .

\section{Material and methods}

\section{A. Definition of the variables}

Milk yield of dairy ewes is defined in France by the production at the milking period only, after one month of suckling. Accordingly, only the decreasing part of the lactation curve is recorded while the milk concentration is increasing throughout that period.

The following variables for this milking period were analysed : milk yield $(M)$, fat and protein yields $(F, P)$, fat and protein contents $(F \%, P \%)$, days of milking $(D)$, daily milk production $(D M)$, as $M$ divided by $D$, and ratio of fat to protein content $(F \%, P \%)$.

Yield traits were corrected for days of milking by the multiplicative factor $k$ of the French dairy sire evaluation scheme (Poutous et al., 1981), as follows :

$$
C M=k M, C F=k F, C P=k P \text {, with } k=220 /(D+60) \text {. }
$$


Above 120 days of milking, yields do not depend any more on days of milking, while under this threshold, correlations between yields and days of milking remain highly positive. Accordingly, the within flock variability is more homogeneous and heritability of the traits is increased (Poutous \& Mocquot, 1975).

Useful yield $(U)$ and content $(U \%)$ were defined as a combination of fat and protein yields or contents, with weightings of 1 and 1.85 respectively :

$$
\begin{aligned}
& U=(C F+1.85 C P) / 2 \\
& \text { and } U \%=(F \%+1.85 P \%) / 2 .
\end{aligned}
$$

$U$ and $U \%$ were the main and secondary selection criteria respectively.

\section{B. Material}

The Lacaune selection nucleus comprises 105000 ewes in 320 herds, for which only milk yield was recorded up to 1985 . However milk composition was experimentally recorded between 1979 and 1981 for 2045 primiparous ewes distributed in 26 year $\times$ flock groups. The present analysis was restricted to the year $\times$ flock groups where at least three young unproven and two proven rams were used, in order to obtain a good connection between flocks in that sample of the selection nucleus. The data set

TABLE 1

\begin{tabular}{|c|c|c|c|}
\hline Analysis & $\begin{array}{l}\text { I } \\
\text { (Henderson's } \\
\text { method I) }\end{array}$ & $\begin{array}{l}\text { II } \\
\text { (Henderson's } \\
\text { method III) }\end{array}$ & $\begin{array}{c}\text { III } \\
\text { (Henderson's } \\
\text { method III) }\end{array}$ \\
\hline Records & 1487 & 1190 & 763 \\
\hline $\begin{array}{l}\text { Sires : } \\
\text { - proven } \\
\text { - sampling }\end{array}$ & $\begin{array}{r}74 \\
102\end{array}$ & $\begin{array}{r}27 \\
102\end{array}$ & $\begin{array}{r}0 \\
102\end{array}$ \\
\hline $\begin{array}{l}\text { Number of daughters of }: \\
\text { - proven sires } \ldots \ldots \ldots \ldots \ldots \ldots \ldots \ldots \ldots\end{array}$ & $\begin{array}{l}724 \\
763\end{array}$ & $\begin{array}{l}427 \\
763\end{array}$ & $\begin{array}{r}0 \\
763\end{array}$ \\
\hline $\begin{array}{l}\text { Number of year } \times \text { flock }(\mathrm{YF}) \text { groups } \ldots \ldots \ldots \\
\text { Average number of daughters per YF } \ldots \ldots \ldots\end{array}$ & $\begin{array}{l}22 \\
67\end{array}$ & $\begin{array}{l}22 \\
54\end{array}$ & $\begin{array}{l}22 \\
34\end{array}$ \\
\hline $\begin{array}{l}\text { Average number of sampling daughters per YF } \\
\text { Average number of sampling sires per YF } \ldots \ldots\end{array}$ & $\begin{array}{r}34 \\
6\end{array}$ & $\begin{array}{r}34 \\
6\end{array}$ & $\begin{array}{r}34 \\
6\end{array}$ \\
\hline $\begin{array}{l}\text { Average number of daughters } \\
\text { of proven sires per YF } \ldots \ldots \ldots \ldots \ldots \ldots \\
\text { Average number of proven sires per YF }\end{array}$ & $\begin{array}{r}33 \\
8\end{array}$ & $\begin{array}{r}20 \\
4\end{array}$ & $\begin{array}{l}\mathbf{0} \\
0\end{array}$ \\
\hline 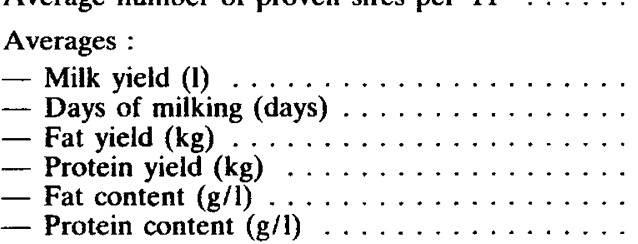 & $\begin{array}{c}146 \\
144 \\
9.82 \\
7.89 \\
67.6 \\
54.3\end{array}$ & $\begin{array}{c}145 \\
146 \\
9.75 \\
7.85 \\
67.3 \\
54.2\end{array}$ & $\begin{array}{c}140 \\
142 \\
9.43 \\
7.57 \\
67.3 \\
54.1\end{array}$ \\
\hline
\end{tabular}

Structure of data sets, and type of analysis 
included 1487 first lactations distributed in 22 year $\times$ flock groups, with 763 ewe lambs born from 102 young rams undergoing progeny test, and 724 born from 74 proven rams. Table 1 summarizes the characteristics of the data set. Out of the proven rams, 27 males with 427 daughters in 22 year $\times$ flock groups were responsible for the greatest part of the connection between flocks.

In order to reduce sampling error, only the young rams tested with at least three daughters were kept in the above data set for the analysis. This threshold was rather low because progeny groups were incomplete in the qualitative recorded sample : the sires had eight daughters on average in the data set while they were tested on 30-40 daughters, for milk yield only, in the whole Lacaune selection nucleus (BARILLET \& ELSEN, 1979).

\section{Methods of analysis}

Genetic parameters were estimated by variance and covariance analysis of half sisters data. In order to avoid bias due to selection (RoBerTSON, 1977), only the 102 young rams were taken into account. However, using the information of all proven sires or of the most widely used proven rams led to a better estimation of fixed effects. The three following analyses were conducted (table 1).

\section{Analysis 1}

Henderson's method 1 (HeNDERSon, 1953) was applied to the data of young ram's daughters, with the sire effect as random. Data were previously corrected for fixed effects (age at lambing, month of lambing, year $\times$ flock) which were estimated on the whole data set with a complete model including young and proven sires effects and environmental effects. Owing to this type of correction, this method was very close to Henderson method II but the reduction in the number of degrees of freedom was not taken into account.

\section{Analysis 2}

Variance and covariance components were estimated by Henderson's method III (Henderson, 1953). The model was derived from Hill et al. (1983), Meyer (1984) and VAN Vleck (1985). Proven sires were considered as fixed effects in order to improve connection between year $\times$ flock. The sample gathered 427 ewe lambs born from the 27 most widely used proven sires and 763 daughters of young unproven rams. The model was the following :

$Y_{i j k l m n}=\mu+M_{i}+A_{j}+Y F_{k}+S_{1}+T_{l m}+E_{i j k l m n}$

with $\mu$ a constant,

$\mathbf{M}_{i}$ the month of lambing effect,

$A_{j}$ the age at lambing effect,

$\mathrm{YF}_{\mathrm{k}}$ the year $\times$ flock effect,

$S_{1}$ the fixed effect of the sires group, 
$T_{l m}$ the within group fixed effect of the proven sire or the random effect of the young ram, assumed to be normally distributed with zero expectation and variance $\sigma_{s}^{2}$.

$E_{i j k m n}$ the residual effect assumed to be normaily distributed with zero expectation and variance $\sigma_{\mathrm{e}}^{2}$.

\section{Analysis 3}

Variance and covariance components were estimated by Henderson's method III from the subsample of the 763 daughters of the 102 young rams. The model included the effects of year $\times$ flock, month and age at lambing as fixed, and of young ram as random.

In the three analyses approximative sampling errors were determined as described by Grossman \& NorTon (1974).

\section{Predicted changes according to the selection criterion}

Predicted changes were estimated as described by RENDEL \& RoBERTSON (1950). Demographic and genetic hypotheses were derived from the actual Lacaune selection scheme (BARILlET \& ELSEN, 1979) : selection pressures on the four gene transmission pathways, sire-son, sire-daughter, dam-son and dam-daughter, were 15, 33, 10 and $70 \mathrm{p}$. 100. Generation intervals were equal to $5.5,4.9,4.5$ and 3.5 years, respectively. Males were progeny tested on 40 daughters, and 45 p. 100 of adult ewes were mated with unproven rams. Table 8 shows the prediction of asymptotic annual genetic changes under these hypotheses according to the selection criterion.

\section{Results}

The estimates of heritability coefficients, genetic and phenotypic standard deviations and genetic correlations are shown in tables $2,4,5$ and 7 respectively.

\section{A. Comparison of the 3 analyses}

Results obtained from the three different analyses were very consistent. Thus, the structure of the data from the unproven sires could be considered as satisfactory. Indeed, the demographic constitution of the Lacaune breed was very favourable as compared to the dairy cattle (MeYER, 1985 ; VAN VLECK, 1985 ; BoIChARD \& BonaïTI, 1987). On average each year $\times$ flock group included 34 ewe lambs born from 6 young rams, with a range of 3 to 12 sires. The same pattern was observed for proven rams with 33 daughters from 8 sires on average, while 20 of them were born from some of the 27 best-represented rams in the data set. More generally speaking, the large number of ewe lambs and of young rams in each year $\times$ flock group may compensate for the possible lack of connection between sires and year $\times$ flock. 


\section{B. Heritability coefficients}

Heritability of the days of milking $(D)$ was rather low, from 0.07 to 0.09 according to the analysis (table 2), thus justifying the partial correction of the yields that are phenotypically very correlated to the days of milking. The corrected variables $(C M, C F$ and $C P$ ) were more heritable than the original variables $(M, F$ and $P$ ) in agreement with Poutous \& Mocquot (1975).

TABLE 2

Estimates of heritabilities for 1 st lactation total milk traits

\begin{tabular}{|c|c|c|c|c|}
\hline \multirow{3}{*}{ Trait } & \multirow{3}{*}{ Abbreviation } & \multicolumn{3}{|c|}{ Analysis } \\
\hline & & I & II & III \\
\hline & & $h^{2}$ & $h^{2}$ & $h^{2}$ \\
\hline Days of milking & $D$ & $0.07 \pm 0.08$ & $0.08 \pm 0.08$ & $0.09 \pm 0.09$ \\
\hline Milk yield & $M$ & $0.29 \pm 0.10$ & $0.27 \pm 0.09$ & $0.27 \pm 0.10$ \\
\hline Daily milk production & $D M$ & $0.28 \pm 0.10$ & $0.29 \pm 0.09$ & $0.26 \pm 0.10$ \\
\hline Corrected milk yield $\ldots \ldots \ldots \ldots$ & $C M$ & $0.32 \pm 0.10$ & $0.32 \pm 0.10$ & $0.30 \pm 0.10$ \\
\hline Fat yield $\ldots \ldots \ldots \ldots$ & $F$ & $0.26 \pm 0.10$ & $0.27 \pm 0.09$ & $0.23 \pm 0.09$ \\
\hline Corrected fat yield & $C F$ & $0.28 \pm 0.10$ & $0.29 \pm 0.09$ & $0.25 \pm 0.10$ \\
\hline Protein yield $\ldots \ldots \ldots \ldots \ldots$ & $P$ & $0.24 \pm 0.09$ & $0.22 \pm 0.09$ & $0.22 \pm 0.09$ \\
\hline Corrected protein yield . . . . & $C P$ & $0.27 \pm 0.10$ & $0.26 \pm 0.09$ & $0.26 \pm 0.10$ \\
\hline Average useful yield & $U$ & $0.28 \pm 0.10$ & $0.27 \pm 0.09$ & $0.26 \pm 0.10$ \\
\hline Fat percent $\ldots \ldots \ldots$ & $F \%$ & $0.49 \pm 0.11$ & $0.62 \pm 0.11$ & $0.57 \pm 0.12$ \\
\hline Protein percent & $p \%$ & $0.47 \pm 0.11$ & $0.53 \pm 0.11$ & $0.52 \pm 0.11$ \\
\hline Average useful content & $U \%$ & $0.58 \pm 0.12$ & $0.65 \pm 0.12$ & $0.66 \pm 0.12$ \\
\hline Fat percent/Protein percent . . & $\mathrm{F} \% / \mathrm{P} \%$ & $0.27 \pm 0.10$ & $0.37 \pm 0.10$ & $0.29 \pm 0.10$ \\
\hline
\end{tabular}

Heritability of milk yield ( $M$ and $C M$ ) varied from 0.27 to 0.32 according to the analysis. This result was in agreement with the average literature data for milking ewes : 0.29 (Dassat \& Mason, 1954 ; Finci, 1957 ; Dassat \& Sartore, 1962 ; BoyAzoglu et al., 1965 ; Soller et al., 1966 ; Calcedo Ordonez, 1968 ; Hinkovski, 1968 ; Bonelli, 1969 ; HoRAK, 1969 ; TeCza, 1969 ; Minev et al., 1971 ; RoMer et al., 1971 ; Yarkin \& Tuncel, 1972 ; Ojeda Sahagun, 1974 ; Casu et al., 1975 ; Flamant \& Casu, 1977 ; Carriedo \& San Primitivo, 1982 ; Mavrogenis, 1982 ; Boichard et al., $1984)$. The heritabilities for fat yield $(0.23$ to 0.29$)$ and protein yield $(0.22$ to 0.27$)$ were similar and slightly smaller than that for milk yield. Estimated heritabilities for contents were much higher and similar, between 0.49 and 0.62 for fat content, and between 0.47 and 0.53 for protein content. These results were consistent with the average literature data for dairy cows, reviewed in 1974 by MaJALA \& HanNa (table 3) and reported by others since that time (DEB et al., 1974 ; TONG et al., 1976 ; HARDIE et al., 1978 ; Hargrove et al., 1981 ; Danell, 1982 ; Karras \& Schlote, 1982 ; Pape $e t$ al., 1983 a ; Alps et al., 1984 ; Meyer, 1984 ; Schneeberger \& HAGger, 1984 ; Meyer, 1985 ; BolchaRd \& Bonaïrı, 1987). However, only two studies of genetic parameters 
for milk composition in dairy ewes are known to us. These estimates were obtained from two experimental flocks in the Sarde breed. The first one, for fat content only (Bonel.LI, 1969) was similar to ours. The second study, involving both protein and fat (CASU et al., 1975 ; Flamant \& CASU, 1977), reported estimates very different from ours, in particular for protein content.

\section{TABLE 3}

Estimates of heritabilities for 1st lactation milk records of dairy cattle (paternal half sister correlation)

\begin{tabular}{|c|c|c|c|c|c|}
\hline Author(s) & $\begin{array}{l}\text { Milk yield } \\
(M)\end{array}$ & $\begin{array}{c}\text { Fat yield } \\
(F)\end{array}$ & $\begin{array}{l}\text { Protein } \\
\text { yield } \\
(P)\end{array}$ & $\begin{array}{c}\text { Fat percent } \\
(F \%)\end{array}$ & $\begin{array}{c}\text { Protein } \\
\text { percent } \\
(P \%)\end{array}$ \\
\hline Maijala \& Hanna (1974) * & $\begin{array}{c}0.25 \pm 0.01 \\
(45)\end{array}$ & $\begin{array}{c}0.24 \pm 0.02 \\
(20)\end{array}$ & $0.29 \pm 0.04$ & $\begin{array}{c}0.47 \pm 0.03 \\
(24)\end{array}$ & $0.45 \underset{(7)}{ \pm} 0.04$ \\
\hline DEB et al. (1974) & $0.40 \pm 0.04$ & $0.31 \pm 0.04$ & & $0.67 \pm 0.06$ & \\
\hline ToNG et al. (1976) & 0.39 & 0.47 & 0.35 & 0.58 & 0.32 \\
\hline HARDIE et al. (1978) & 0.27 & 0.38 & & 0.64 & \\
\hline HARGROVE et al. (1981) & $0.23 \pm 0.07$ & $0.26 \pm 0.07$ & $0.22 \pm 0.07$ & $0.71 \pm 0.09$ & $0.64 \pm 0.09$ \\
\hline Danell (1982) & $0.31 \pm 0.06$ & $0.28 \pm 0.05$ & & $0.48 \pm 0.07$ & \\
\hline KarRas \& Schlote (1982) & 0.28 & 0.25 & & 0.39 & \\
\hline PAPE et al. (1983a) . . . . . . & 0.25 & 0.15 & 0.24 & 0.41 & 0.29 \\
\hline ALPS et al. (1984) & 0.23 & 0.21 & 0.21 & 0.39 & 0.46 \\
\hline MEYER (1984) & $0.28 \pm 0.02$ & $0.27 \pm 0.03$ & & & \\
\hline SCHNEEBERGER \& HAGGER (1984) & 0.28 & & & 0.61 & 0.72 \\
\hline Meyer (1985) $\ldots \ldots \ldots$ & 0.17 & 0.15 & 0.13 & 0.38 & 0.25 \\
\hline BoICHARd \& BonaÏTI (1987) * & $0.31 \underset{(3)}{ \pm} 0.03$ & $0.28 \underset{(3)}{ \pm} 0.03$ & $0.25 \underset{(3)}{ \pm} 0.03$ & $0.59 \pm 0.05$ & $\begin{array}{c}0.57 \pm 0.05 \\
(3)\end{array}$ \\
\hline Total unweighted mean & $0.26(59)$ & $0.25(33)$ & $0.26(14)$ & $0.49(37)$ & $0.47(16)$ \\
\hline
\end{tabular}

* Average literature data (number of estimates).

\section{Genetic standard deviation estimates (table 4)}

Fat yield and content were more variable than protein. According to the analyses, genetic standard deviations ranged respectively from 1.24 to $1.30 \mathrm{~kg}$ for $C F, 0.94$ to $0.95 \mathrm{~kg}$ for $C P, 4.3$ to $4.9 \mathrm{~g} / 1$ for $F \%$ and 2.4 to $2.5 \mathrm{~g} / 1$ for $P \%$. The ratio of fat to protein standard deviations reached about 1.30 for yields and 1.85 for contents. Similarity of the results between species has to be pointed out. Indeed the estimates of the ratio reported by Hill et al. (1983) and BoichaRd \& BonAḯTI (1987) are very close to ours. Therefore fat traits seem more likely to vary than protein ones. 
TABLE 4

Phenotypic $\left(\sigma_{P}\right)$ and genetic $\left(\sigma_{G}\right)$ standard deviations for first lactation total milk traits (1)

\begin{tabular}{|c|c|c|c|c|c|c|c|}
\hline \multirow{3}{*}{ Trait } & \multirow{3}{*}{$\begin{array}{l}\text { Abbre- } \\
\text { viation }\end{array}$} & \multicolumn{6}{|c|}{ Analysis } \\
\hline & & \multicolumn{2}{|c|}{$\mathbf{I}$} & \multicolumn{2}{|c|}{ II } & \multicolumn{2}{|c|}{ III } \\
\hline & & $\sigma_{\mathrm{P}}$ & $\sigma_{\mathrm{G}}$ & $\sigma_{\mathrm{P}}$ & $\sigma_{\mathrm{G}}$ & $\sigma_{\mathbf{P}}$ & $\sigma_{\mathrm{G}}$ \\
\hline Days of milking & $D$ & 16 & 4 & 17 & 5 & 16 & 5 \\
\hline$\ldots \ldots \ldots \ldots$ & $M$ & 37.2 & 19.9 & 37.5 & 19.4 & 36.8 & 19.1 \\
\hline Daily milk production (l) & $D M$ & 0.239 & 0.126 & 0.234 & 0.125 & 0.238 & 0.123 \\
\hline Corrected milk yield (1) (2) $\ldots \ldots$ & $C M$ & 36.8 & 20.7 & 36.4 & 20.5 & 36.7 & 20.2 \\
\hline Fat yield $(\mathrm{kg}) \quad \ldots \ldots \ldots \ldots$ & $F$ & 2.47 & 1.25 & 2.52 & 1.31 & 2.44 & 1.18 \\
\hline Corrected fat yield $(\mathrm{kg})(2) \ldots \ldots$ & $C F$ & 2.41 & 1.28 & 2.40 & 1.30 & 2.40 & 1.24 \\
\hline Protein yield $(\mathrm{kg})$ & $P$ & 1.91 & 0.93 & 1.94 & 0.92 & 1.89 & 0.89 \\
\hline Corrected protein yield $(\mathrm{kg})(2) \ldots$ & $C P$ & 1.86 & 0.95 & 1.85 & 0.94 & 1.85 & 0.94 \\
\hline Average useful yield $(\mathrm{kg})(3) \ldots$ & $U$ & 2.88 & 1.52 & 2.87 & 1.49 & 2.87 & 1.45 \\
\hline Fat percent $(g / l) \ldots \ldots \ldots \ldots$ & $F \%$ & 6.2 & 4.3 & 6.2 & 4.9 & 6.3 & 4.7 \\
\hline Protein percent $(g / 1) \ldots \ldots \ldots$ & $P \%$ & 3.5 & 2.4 & 3.5 & 2.5 & 3.5 & 2.5 \\
\hline Average useful percent $(\mathrm{g} / \mathrm{l})(4) \ldots$ & $U \%$ & 5.5 & 4.2 & 5.5 & 4.5 & 5.5 & 4.5 \\
\hline Fat percent/Protein percent $\ldots \ldots$ & $F \% / P \%$ & 0.103 & 0.054 & 0.099 & 0.061 & 0.103 & 0.055 \\
\hline \multicolumn{8}{|c|}{$\begin{array}{l}\text { (1) After } 25 \text { days of suckling. } \\
\text { (2) Multiplicative correction for days of milking. } \\
\text { (3) }(C F+1.85 C P) / 2 \text {. } \\
\text { (4) }(F \%+1.85 P \%) / 2 \text {. }\end{array}$} \\
\hline
\end{tabular}

\section{Estimates of genetic correlations}

Milk yield was more strongly correlated with protein yield (0.92 to 0.94$)$ than with fat yield, 0.82 to 0.86 (table 5). Correlation between fat and protein yields took an intermediate position between the two previous ones $(0.90$ to 0.93$)$. The average literature data for dairy cow show a very similar trend (table 6), the correlation between milk and protein yields being the highest (MaIJALA \& HANNA, 1974 ; Tong et al., 1976 ; HARGROVE et al., 1981 ; PAPE et al., 1983 b ; AlPS et al., 1984 ; MeYer, 1985 ; BoICHARD \& BonAÏTI, 1987). The estimated genetic correlation between fat and protein contents fell within a range of 0.75 to 0.81 and was higher than the usual value published for dairy cows (0.56). However, our estimates were more consistent with the two results given for the Sarde breed (CASU et al., 1975 ; Flamant \& Casu, 1977). Anyway, in both species a preferential evolution of one of the contents should be easier to obtain than for one of the matter yields, since genetic correlation is lower between contents than between yields.

In our sample, genetic correlations between milk yield and concentration $(-0.34$ to - 0.51) were clearly negative (table 5). That opposition is not so strong in dairy cows (table 6), although more recent studies (HARgrove et al., 1981 ; PAPE et al., 1983 b ; Alps et al., 1984 ; Schneeberger \& HAGger, 1984 ; Meyer, 1985 ; Boichard \& BonAÏT1, 1987) reported strong negative correlations. Moreover, the genetic correla- 


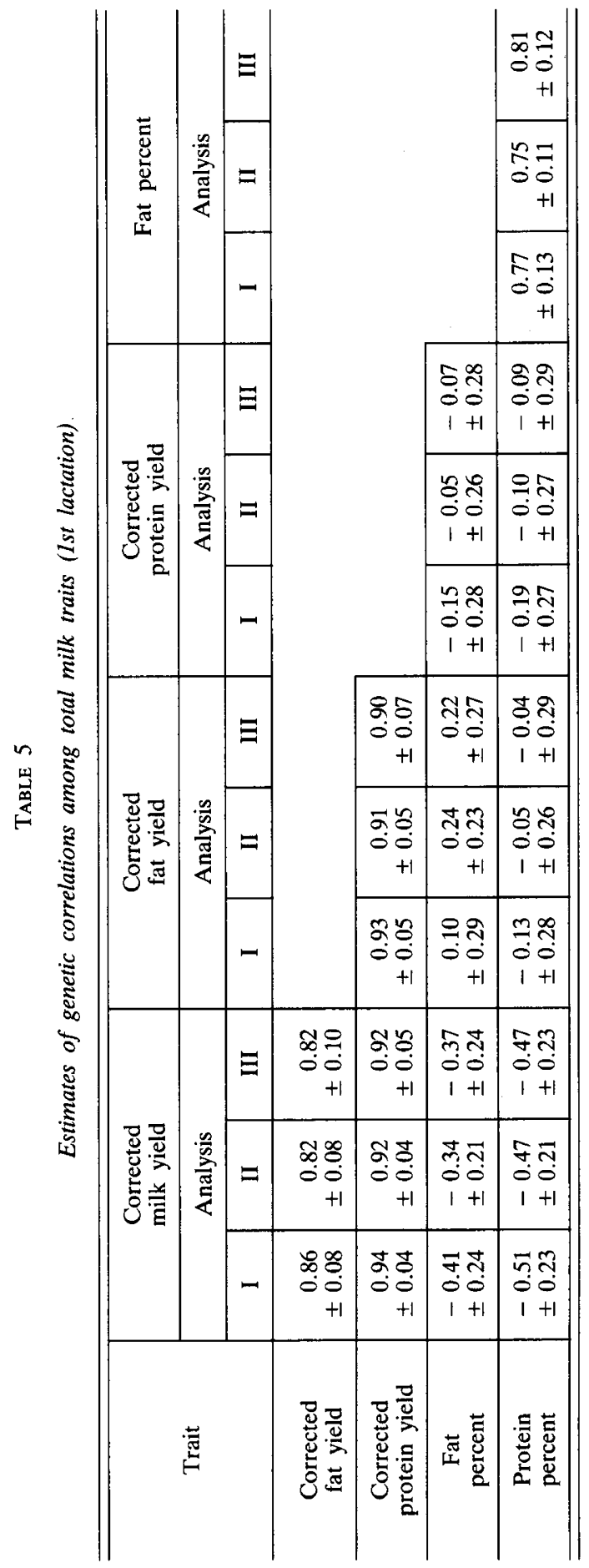


tion between milk yield and protein content $(-0.47$ to -0.51$)$ was stronger than between milk yield and fat content $(-0.34$ to -0.41$)$. Recent papers showed a similar trend in dairy cows.

Genetic correlations between fat yield and content were always positive and ranged from 0.10 to 0.24 (table 5). This observation was in agreement with results obtained in dairy cows (table 6) : indeed the average literature data is 0.30 without one negative estimate. However, the estimated correlation between protein yield and content was negative, from -0.09 to -0.19 . Similarly, correlations between fat content and protein yield $(-0.05$ to -0.15$)$ or between protein content and fat yield $(-0.04$ to -0.13$)$ were slightly negative. Only the relationship between protein yield and content appeared rather atypical, as published studies show an average of 0.15 over 14 estimates with only 4 negative results (table 6 ). The negative cross-correlations were more usual: indeed the average over 14 estimates between protein yield and fat content is equal to -0.08 , with 12 negative results, while between protein content and fat yield it reaches 0.04 over 14 estimates with 7 negative (table 6).

\section{Discussion}

The present results generally agree with already published data for dairy cows for heritability estimates, for difference between variabilities of fat and protein matter and for genetic correlations between matter yields and milk yield, between milk yield and both contents, between fat yield and content.

However, the genetic correlation between both contents seems to be higher than for dairy cows. This difference could be due to the lack of selection on milk concentration in dairy ewes, while a selection on fat content has been applied on dairy cows for a long time. It may also be explained by a difference between species, or between traits, which are not exactly the same : the average content is considered over the whole lactation for the cow but only after a month of suckling for the ewe. This difference could also be due to the low accuracy of the present estimate, obtained from a rather small data sample. Indeed, the standard error of the estimated genetic correlation between contents was close to 0.11 (table 7).

Neither was the correlation between protein yield and both contents accurately estimated. These relationships were low but their sign could not be clearly established. However, the same question remains without answer for dairy cows. The number of estimates has to be pointed out, being half the corresponding number of estimates for fat yield (table 6), because of the lack of systematic recording of protein content in all countries.

In France, the sheep milk is exclusively processed into a specific cheese known for its high ratio of fat to dry content. For this reason, useful matter yield $(U)$ and content $(U \%)$, defined as above, were chosen as main and secondary selection criteria (BARILlet, 1985). Since each content is weighted with the reciprocal of its standard deviation, $U \%$ gives the same economic value to an increase of one genetic standard deviation in fat as well as in protein content. So the genetic correlation of $U \%$ was the same with $F \%$ as with $P \%, 0.94$ and 0.93 respectively (table 7 ). The main selection criterion $U$ can be considered as a cheese output, i.e. a dry matter yield $(F+P)$, by 


\begin{tabular}{|c|c|c|c|c|c|c|c|c|c|c|c|c|}
\hline $\begin{array}{l}\stackrel{0}{2} \\
\times \\
\dot{2} \\
\end{array}$ & $\stackrel{n}{0} \underset{+1}{\stackrel{8}{0}}$ & $\stackrel{n}{6}$ & & $\begin{array}{r}50 \\
0 \\
0 \\
0 \\
+1\end{array}$ & & $\begin{array}{l}\infty \\
\stackrel{\infty}{0} \\
0\end{array}$ & $\mid \begin{array}{l}0 \\
\stackrel{0}{0} \\
0\end{array}$ & & ల్లి & $\underset{+1}{8} \stackrel{0}{0} \underset{0}{0}$ & $\stackrel{\mathscr{n}}{\circ} \stackrel{\Xi}{\varrho}$ & \\
\hline $\begin{array}{l}\stackrel{0}{a} \\
\times \\
2\end{array}$ & 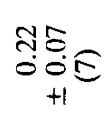 & $\stackrel{5}{0}$ & & $\begin{array}{r}8: 2 \\
0 \\
0 \\
+1\end{array}$ & & & $\frac{m}{0}$ & & $\stackrel{8}{8}$ & $\underset{+1}{\Delta 0} \stackrel{0}{0}$ & $\stackrel{n}{0} \underset{\Xi}{\Xi}$ & \\
\hline $\begin{array}{l}20 \\
\frac{2}{2} \\
x\end{array}$ & 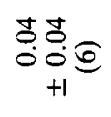 & $\begin{array}{l}0 \\
0 \\
1\end{array}$ & & $\begin{array}{l}2 \pm \\
0 \\
1+1\end{array}$ & & $\begin{array}{l}3 \\
0 \\
1\end{array}$ & $\begin{array}{l}0 \\
0 \\
0 \\
1\end{array}$ & & $\begin{array}{c}\stackrel{m}{m} \\
\stackrel{0}{1} \\
1\end{array}$ & 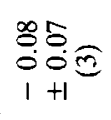 & $\stackrel{\circ}{\circ} \underset{1}{\stackrel{\sigma}{\Xi}}$ & \\
\hline $\begin{array}{l}\stackrel{0}{\vdots} \\
x \\
1\end{array}$ & $\underset{+1}{0} 0$ & $\stackrel{\circ}{\circ}$ & & $\begin{array}{c}m \\
0 \\
0 \\
0 \\
+1\end{array}$ & & $\begin{array}{l}\bar{N} \\
0 \\
1\end{array}$ & $\begin{array}{c}0 \\
0 \\
0 \\
1\end{array}$ & & $\begin{array}{c}n \\
0 \\
1\end{array}$ & $\begin{array}{c}250 \\
0 \\
0 \\
1+1\end{array}$ & 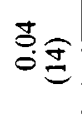 & \\
\hline $\begin{array}{l}\text { वे } \\
x \\
x\end{array}$ & $\stackrel{\substack{0 \\
0}}{0}$ & $\tilde{\sigma}$ & & 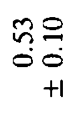 & 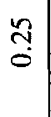 & $\stackrel{\tilde{y}}{0}$ & $\begin{array}{c}n \\
0 \\
0\end{array}$ & & ஜ̊ & $\underset{+1}{\operatorname{mos}}$ & ల్లి & \\
\hline $\begin{array}{l}2 \\
x \\
2\end{array}$ & $\stackrel{\infty}{\infty} \underset{+1}{\infty} \underset{0}{0}$ & $\stackrel{n}{n}$ & & 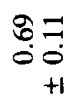 & & $\stackrel{\infty}{\stackrel{\infty}{0}}$ & $\begin{array}{l}\bar{\infty} \\
\dot{0}\end{array}$ & & $\overrightarrow{5}$ & 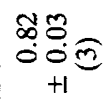 & $\stackrel{\infty}{\circ} \underset{\Xi}{\Xi}$ & \\
\hline $\begin{array}{l}\stackrel{0}{2} \\
\times \\
z\end{array}$ & 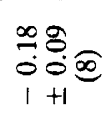 & 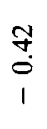 & & $\begin{array}{l}\infty \\
\stackrel{0}{0}= \\
1+1 \\
1+1\end{array}$ & & $\begin{array}{l}n \\
\tilde{0} \\
1\end{array}$ & $\left|\begin{array}{l}\infty \\
\tilde{n} \\
0 \\
1\end{array}\right|$ & \begin{tabular}{l}
0 \\
\multirow{2}{0}{} \\
1
\end{tabular} & $\begin{array}{l}+ \\
0 \\
0 \\
1\end{array}$ & 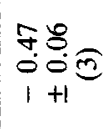 & $\stackrel{\text { mై }}{0}$ & \\
\hline $\begin{array}{l}0^{0} \\
x \\
z\end{array}$ & 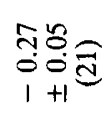 & $\begin{array}{l}\hat{N} \\
0 \\
1\end{array}$ & $\begin{array}{l}= \\
0 \\
1\end{array}$ & 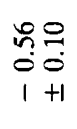 & 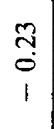 & $\begin{array}{c}n \\
0 \\
1\end{array}$ & \begin{tabular}{c}
\multirow{2}{\jmath}{} \\
0 \\
1
\end{tabular} & $\begin{array}{c}n \\
0 \\
1\end{array}$ & 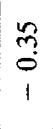 & 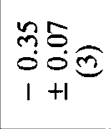 & స్తి & \\
\hline $\begin{array}{l}2 \\
x \\
z\end{array}$ & $\begin{array}{c}0 \\
0 \\
0 \\
0 \\
0 \\
+1\end{array}$ & $\stackrel{\infty}{0}$ & & $\begin{array}{r}05 \\
00 \\
0 \\
+1\end{array}$ & & $\tilde{\sigma}$ & $\begin{array}{l}\infty \\
0 \\
0\end{array}$ & & бa & 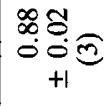 & $\stackrel{\infty}{0} \underset{\Xi}{\Phi}$ & \\
\hline $\begin{array}{l}x \\
x \\
z\end{array}$ & 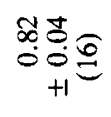 & $\stackrel{f}{0}$ & $\stackrel{?}{\circ}$ & $\begin{array}{r}q \infty \\
00 \\
+1\end{array}$ & $\begin{array}{l}\infty \\
\infty \\
0\end{array}$ & 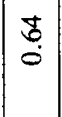 & $\begin{array}{l}\infty \\
0 \\
0\end{array}$ & & $\stackrel{0}{0}$ & 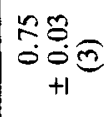 & $\stackrel{5}{\stackrel{5}{0}}$ & $\dot{\vec{\theta}}$ \\
\hline 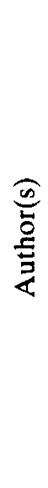 & 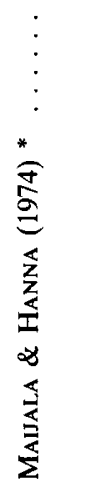 & 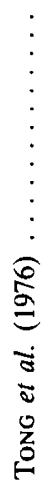 & 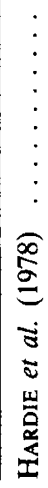 & 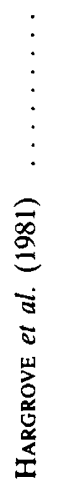 & 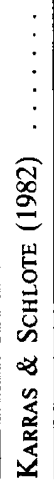 & 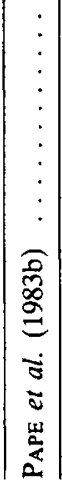 & 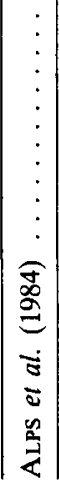 & 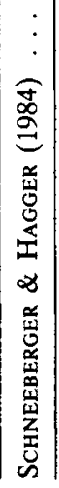 & 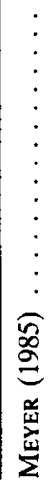 & 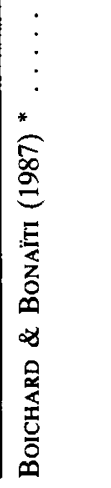 & 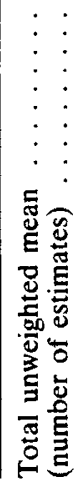 & 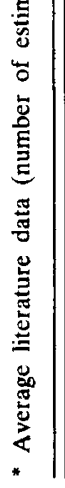 \\
\hline
\end{tabular}




\begin{tabular}{|c|c|c|c|c|c|c|c|c|c|c|c|c|c|}
\hline 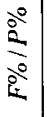 & $\Xi$ & $\infty$ & - & 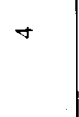 & $\bar{m}$ & $\bar{m}$ & $\theta$ & $\begin{array}{l}+ \\
\end{array}$ & 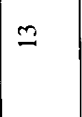 & 咅 & $\frac{\infty}{1}$ & $\bar{m}$ & $\hat{n}=$ \\
\hline 今̊ & $\tilde{N}$ & $\bar{N}$ & i & i & $r$ & $m$ & $\begin{array}{c}N \\
1\end{array}$ & r & $\begin{array}{c}m \\
1\end{array}$ & 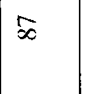 & $\underset{\propto}{\propto}$ & $\begin{array}{r}x= \\
+1\end{array}$ & $\underset{+1}{\stackrel{\infty}{\infty}}$ \\
\hline$\stackrel{2}{2}$ & $\mathscr{0}$ & $\underset{1}{i}$ & $\stackrel{\infty}{\infty}$ & $\begin{array}{l}\text { ले } \\
1\end{array}$ & $\infty$ & $\frac{m}{1}$ & $\begin{array}{c}1 \\
N\end{array}$ & r & $\frac{0}{1}$ & $n$ & $\begin{array}{r}n= \\
+1\end{array}$ & $\begin{array}{r}\Omega^{m} \\
+1\end{array}$ & $\begin{array}{r}\approx \approx \\
+1\end{array}$ \\
\hline $0^{\circ}$ & $\hat{\imath}$ & $=$ & $\stackrel{\imath}{1}$ & $\frac{9}{1}$ & $\bar{\sim}$ & $\stackrel{\infty}{\sim}$ & $\sim$ & $\begin{array}{l}n \\
1\end{array}$ & in & $\begin{array}{r}\hat{\sigma}= \\
+1\end{array}$ & $\begin{array}{r}2= \\
+1\end{array}$ & $\begin{array}{r}\Delta m \\
+1\end{array}$ & $\begin{array}{r}20 \\
+1\end{array}$ \\
\hline$D$ & ల్ల & $\Xi$ & $\bar{\sigma}$ & $\mathscr{2}$ & $\Xi$ & $\stackrel{\circ}{\circ}$ & $\curvearrowleft$ & 8 & $\begin{array}{r}\Sigma^{a} \\
+1\end{array}$ & $\begin{array}{r}-\approx \\
+1\end{array}$ & $\begin{array}{cc}\infty & 0 \\
1 & +1\end{array}$ & $\begin{array}{r}0 \approx \\
+1\end{array}$ & $\begin{array}{r}x \\
+1\end{array}$ \\
\hline 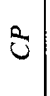 & จิ & Z & $\Omega$ & 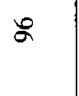 & 8 & ম & $\approx$ & $\begin{array}{r}20 \\
+1\end{array}$ & $\stackrel{\infty}{a-}+$ & $\begin{array}{ll}n & 0 \\
1 & +1\end{array}$ & $\begin{array}{c}9 \approx \\
1+1\end{array} \mid$ & $\begin{array}{ll}\infty & \approx \\
1 & +1\end{array}$ & $\begin{array}{r}-8 \\
+1\end{array}$ \\
\hline$a$ & ๙ & 5 & $\vec{\infty}$ & \& & $\approx$ & $\bar{\sigma}$ & $\begin{array}{r}\approx a \\
+1\end{array}$ & $\begin{array}{r}\mathscr{2} \\
+1 \\
+1\end{array}$ & $\begin{array}{r}2 \sim \\
+1\end{array}$ & $\begin{array}{r}=\tilde{N} \\
+1\end{array}$ & $\left|\begin{array}{l}n g \\
1+1\end{array}\right|$ & $\begin{array}{r}05 \\
+1\end{array}$ & $\begin{array}{r}0 \mathrm{~N} \\
+1\end{array}$ \\
\hline 它 & $\vec{m}$ & $\bar{a}$ & $\infty$ & $\alpha$ & 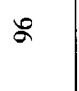 & $\begin{array}{r}2 a \\
+1\end{array}$ & $\begin{array}{r}2+ \\
+1\end{array}$ & $\begin{array}{r}a^{n} \\
+1\end{array}$ & $\begin{array}{r}5 \\
+1\end{array}$ & $\begin{array}{r}\stackrel{\sim}{\sim} \\
+1\end{array}$ & $\begin{array}{ll}n & 0 \\
1 & +1\end{array}$ & $\begin{array}{r}\varrho \underset{\sim}{ \pm} \\
+1\end{array}$ & $\begin{array}{r}q u \\
+1\end{array}$ \\
\hline L & $\bar{n}$ & $\Xi$ & $F$ & $\infty$ & $\begin{array}{r}\hat{N}^{a} \\
+1\end{array}$ & $\begin{array}{r}2 \sim \\
+1\end{array}$ & $\begin{array}{r}\text { t } \\
+1\end{array}$ & $\begin{array}{r}\infty \\
+1\end{array}$ & $\begin{array}{r}\sigma \\
+1\end{array}$ & $\begin{array}{r}m \widetilde{N} \\
+1\end{array}$ & $\begin{array}{c}\sim \approx \\
+1 \\
\end{array}$ & $\begin{array}{r}-2 \\
+1 \\
+1\end{array}$ & 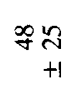 \\
\hline $\mathbf{Z}$ & $\ddot{\sim}$ & $\approx$ & $\hat{a}$ & $\begin{array}{r}\text { 르으 } \\
+1\end{array}$ & $\begin{array}{r}2= \\
+1\end{array}$ & $\begin{array}{r}\infty \infty \\
+1\end{array}$ & $\begin{array}{r}\hat{\infty}^{-} \\
+1\end{array}$ & $\begin{array}{r}\sigma \sigma \\
+1\end{array}$ & $\begin{array}{r}\sin ^{n} \\
+1\end{array}$ & $\begin{array}{c}\vec{m} \\
1+1\end{array}$ & $\begin{array}{r}F \vec{N} \\
1+1\end{array}$ & 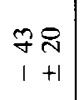 & $\begin{array}{c}\infty \underset{N}{N} \\
1+1\end{array}$ \\
\hline $\mathbf{g}$ & 0 & $\hat{\infty}$ & $\begin{array}{r}29 \\
+1\end{array}$ & $\begin{array}{r}8- \\
+1\end{array}$ & $\begin{array}{r}n= \\
+1\end{array}$ & $\begin{array}{r}\infty \\
+1\end{array}$ & $\begin{array}{r}\infty \\
+1\end{array}$ & 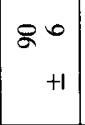 & $\begin{array}{r}\infty^{-} \\
+1\end{array}$ & $\begin{array}{c}\mathcal{y} \\
1+1\end{array} \mid$ & $\left|\begin{array}{c}\text { 듀 } \\
1+1\end{array}\right|$ & $\begin{array}{c}\bar{n} \approx \\
1+1\end{array}$ & $\begin{array}{l}3 \text { ते } \\
1+1\end{array}$ \\
\hline$\Sigma$ & f & $\begin{array}{r}\hat{\sim}^{a} \\
+1\end{array}$ & $\begin{array}{r}2 n \\
+1\end{array}$ & $\begin{array}{r}\mathscr{2} \\
+1\end{array}$ & $\begin{array}{r}\infty \\
\infty \\
+1\end{array}$ & $\begin{array}{r}\infty \\
+1\end{array}$ & $\begin{array}{c}2+ \\
+1\end{array}$ & $\begin{array}{r}\sigma \\
+1 \\
+1\end{array}$ & $\begin{array}{r}+1 \\
z \\
+\end{array}$ & $\left|\begin{array}{cc}\text { กิ } \\
1+1\end{array}\right|$ & $\mid \begin{array}{cc}\text { gे } \\
1+1 \\
1+1\end{array}$ & $\begin{array}{c}-\vec{\pi} \\
1+1\end{array}$ & $\begin{array}{r}n g \\
+1\end{array}$ \\
\hline 0 & $\begin{array}{r}\infty \infty \\
+1\end{array}$ & $\begin{array}{r}0 \approx \\
+1\end{array}$ & $\begin{array}{r}0 \\
+1 \\
+1\end{array}$ & $\begin{array}{r}\approx 尺 \\
+1\end{array}$ & $\begin{array}{r}m q \\
+1\end{array}$ & $\begin{array}{r}5 g \\
+1\end{array}$ & $\begin{array}{r}n z \\
+1\end{array}$ & $\begin{array}{r}q \vec{n} \\
+1\end{array}$ & $\begin{array}{r}n= \\
+1\end{array}$ & $\begin{array}{r}\infty \\
+1 \\
+\infty\end{array}$ & $\begin{array}{cc}\infty & 0 \\
+ & + \\
+1\end{array}$ & $\begin{array}{c}\infty \\
\infty \\
+1\end{array}$ & $\begin{array}{r}\nabla ⿱ 0 \\
+1\end{array}$ \\
\hline & $\theta$ & $\Sigma$ & $\underset{\Delta}{\Delta}$ & $\bar{U}$ & L & $\frac{x}{0}$ & 2 & $\tilde{u}$ & $>$ & לे & $\stackrel{\circ}{\circ}$ & $\stackrel{\diamond}{\$}$ & $\frac{\vdots}{2}$ \\
\hline
\end{tabular}




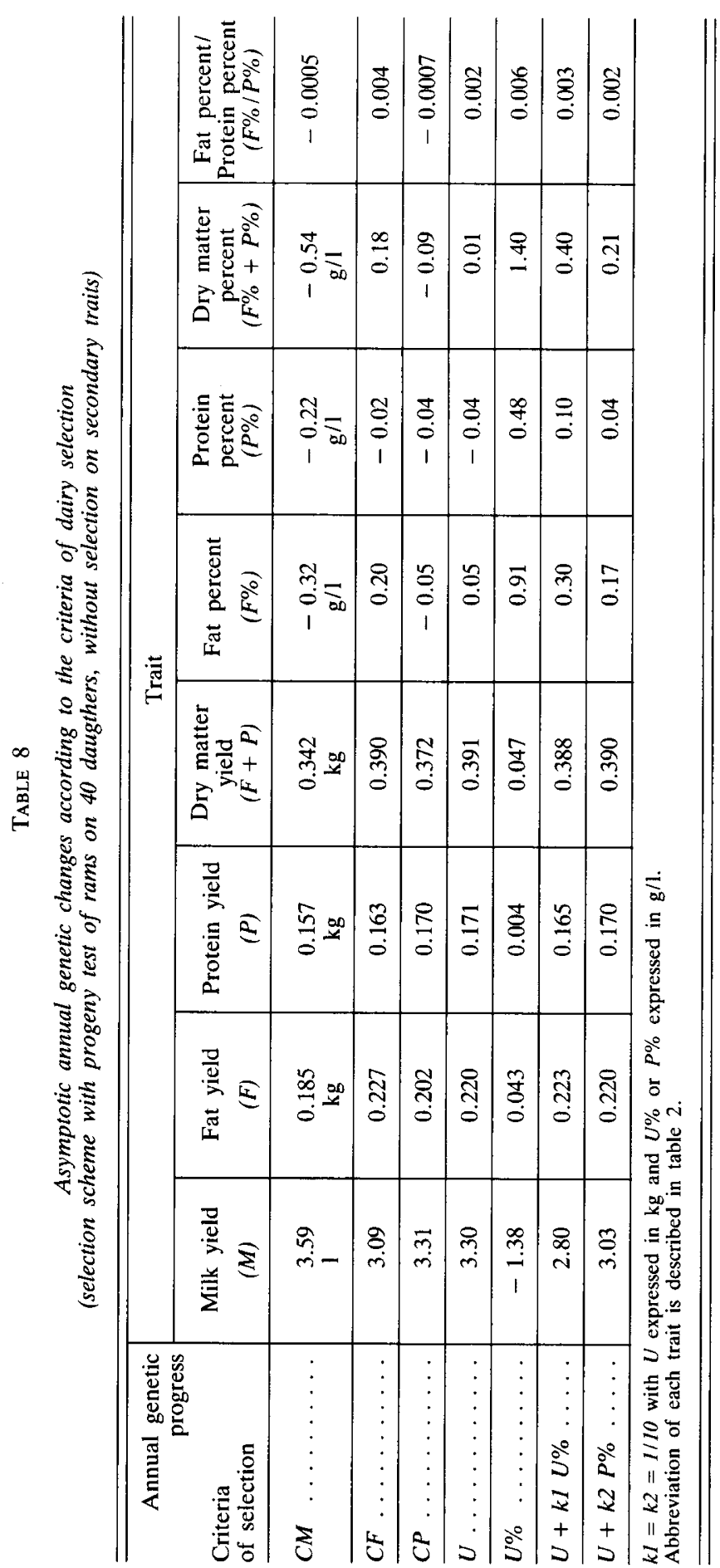


the ewe. In the same way, the secondary criterion represents on one hand the cheese yield best predicted by the dry matter content $(F \%+P \%)$, and on the other hand the fat to dry matter ratio in the cheese, corresponding to the ratio of fat to protein contents in the milk (table 8). It can be pointed out that the ratio $F \% / P \%$ is to be monitored in the milking ewe, while the reciprocal ratio $P \% / F \%$ is of major interest in dairy cattle (Maljala \& HANNA, 1974 ; BoichaRd \& Bonaïti, 1987). The genetic correlation between $U$ and $U \%$ was null (table 7). Such a result was already known in dairy cattle : using different weightings (1 to 1.20 ) of protein relative to fat, BonAïTs \& Mocquot (1982), Alps \& AverdunK (1984) and Boichard \& Bonaïti (1987) obtained null or slightly positive estimates of genetic correlation between useful yield and content.

Although selecting exclusively on $U$ should maintain dry matter content at a stable genetic level, it should not be advised in dairy ewes. According to the sign of the genetic correlation between protein yield and both contents, this selection leads to a possible decrease in protein content and to an almost certain increase in fat content. These results are clearly shown by the expected genetic changes (table 8 ) based on the demographic hypotheses of BARILLET \& ELSEN (1979). Of course, selection on $U$ gives the largest yearly response in dry matter yield $(F+P), 0.391 \mathrm{~kg}$, while maintaining dry matter content. But fat content increases by $0.05 \mathrm{~g} / \mathrm{l}$ each year while protein content decreases by $0.04 \mathrm{~g} / \mathrm{l}$. A regular decrease in $P \%$ may have, in the long term, negative technological consequences. Accordingly, it seems preferable to use as selection criterion a combination of $U$ and $U \%$, or $U$ and $P \%$. As shown in table 8 , the first option, with weighting 1 for $U$ expressed in $\mathrm{kg}$ and 0.1 for $U \%$ expressed in $\mathrm{g} / \mathrm{l}$, is rather satisfactory. The response in the main trait $(F+P)$ is almost the same as with selection on $U$ only, while positive yearly gains are expected for secondary traits : $+0.30 \mathrm{~g} / 1$ for fat content, $+0.10 \mathrm{~g} / \mathrm{l}$ for protein content, +0.003 for $F \% /$ $P \%$.

\section{Conclusion}

This study was the first on-farm estimation of genetic parameters for dairy traits (milk yield and composition) in milking ewes. The present estimates were generally consistent with those obtained in dairy cows for 25 years. Therefore in the Lacaune breed, selection on milk yield must be discarded and replaced by the selection on useful yield. Because of the genetic relationship between protein content and protein and fat yields, the selection criterion must include both useful yield and content instead of useful yield alone.

Since 1985, fat and protein contents were recorded with a simpler procedure in the Lacaune breed (BARILlet et al., 1986) and, since 1986, an experimental A type recording procedure was set up in some flocks of the selection nucleus in the Manech and Basco-Béarnaise breeds. In few years we will be able to obtain more accurate estimates of genetic parameters for the main French breeds from larger data samples.

Received November 25, 1986.

Accepted April 1, 1987. 


\section{References}

Alps H., Averdunk G., 1984. Genetische Parameter für die Merkmale der Milchleistung unter besonderer Berücksichtigung des Eiweisses beim Fleckvieh in Bayern. II. Summe aus Eiweiss und Fett. Züchtungskunde, 56, 99-107.

Alps H., Reklewski Z., Averdunk G., 1984. Genetische Parameter für die Merkmale der Milchleistung unter besonderer Berücksichtigung des Eiweisses beim Fleckvieh in Bayern. I. Einzelmerkmale. Züchtungskunde, 56, 88-98.

Barillet F., 1985. Amélioration génétique de la composition du lait des brebis : l'exemple de la race Lacaune. Thèse de Docteur Ingénieur, INA Paris-Grignon.

BarIllet F., Elsen J.M., 1979. Optimisation de l'utilisation de l'insémination artificielle dans les schémas de sélection des ovins. $5^{e}$ Journées de la Recherche ovine et caprine, Paris, 5-6 décembre 1979, 186-204, ITOVIC-SPEOC, Paris.

Barillet F., Elsen J.M., Roussely M., 1986. Optimization of a selection scheme for milk composition and yield in milking ewes : example of the Lacaune breed. 3rd World Congress on Genetics applied to Livestock Production, Lincoln, July 16-22, 1986, Dickerson G.E., JoHNSON R.K., (ed.), 658-664, University of Nebraska, Lincoln.

Boichard D., Barillet F., Bodin L., 1984. Influence des modalités de reproduction sur la production laitière à la traite des agnelles de race ovine de Lacaune. $9^{*}$ Journées de la Recherche ovine et caprine, Paris, 4-5 décembre 1984, 399-414, ITOVIC-SPEOC, Paris.

BoICHARD D., BonaïTI B., 1987. Genetic parameters for first lactation dairy traits in Friesian, Montbéliarde and Normande breeds. Génét. Sél. Evol., 19, 3, 337-350.

Bonaïrı B., MocQuot J.C., 1982. Etudes sur la production laitière des bovins. IV. Paramètres génétiques en première lactation. Ann. Génét. Sél. Anim., 14, 161-176.

Bonell P., 1969. Aspetti quantitativi della lattazione e delle componenti grasse del latte di pecora Sarda di primo parto. Coefficienti di ereditabilita. Riv. Zootec., 42, 504-510.

Boyazoglu J.G., Poly J., Poutous M., 1965. Aspects quantitatifs de la production laitière des brebis. III. Coefficients d'héritabilité. Ann. Zootech., 14, 53-63.

Calcedo Ordonez V., 1968. La mejora de los ovinos de raza Churra. II. Control lechero maximo (C.L.M.) y su correlacion fenotipica con la produccion total. Veterinaria, 33, 597-601.

Carriedo J.A., San Primitivo F., 1982. Estudio genetico de los factores que influyen en la produccion lactea del ganado ovino. III. Heredabilidad y repetibilidad. Inf. Tec. Econ. Agrar., 47, 29-34.

Casu S., Carta R., Flamant J.C., 1975. Amélioration génétique de la production laitière des brebis Sardes. Ann. Génét. Sél. Anim., 7, 73-90.

DANELl B., 1982. Studies on lactation yield and individual test-day yields of Swedish dairy cows. II. Estimates of genetic and phenotypic parameters. Acta Agric. Scand., 32, 83-92.

Dassat P., Mason J.L., 1954. Heritability of milk yield of sheep. Caryologia, 6, 750-753.

Dassat P., Sartore G., 1962. Ricerche sugli aspetti genetici dei principali constituenti del latte di pecora. Atti Assoc. Genet. Italiana., 7, 136-137.

Deb R.N., Gobble J.L., Hargrove G.L., Thoele H.W., 1974. Lactation records of Jersey cattle in Pennsylvania : season of calving, phenotypic trend, heritability, and genetic trend. J. Dairy Sci., 57, 884-888.

Fincı M., 1957. The improvement of the Awassi breed of sheep in Israël. Bull. Res. Counc. Israël. $6 \mathrm{~B}, 106 \mathrm{p}$.

Flamant J.C., Casu S., 1977. Amélioration génétique de la production laitière des brebis Sardes. II. Facteurs de variation génétiques et non génétiques des performances de brebis ayant réalisé 2 lactations. Ann. Génét. Sél. Anim., 9, 203-217.

Grossman M., Norton H.W., 1974. Simplification of the sampling variance of the correlation coefficients. Theor. Appl. Genet., 44, 332-333.

Hardie A.R., Jensen E.L., Tyler W.J., 1978. Genetic and economic implications of single trait selection for protein and solids-non-fat. J. Dairy Sci., 61, 96-101.

Hargrove G.L., Mbah D.A., Rosenberger J.L., 1981. Genetic and environmental influences on milk and milk component production. J. Dairy Sci., 64, 1593-1597.

Henderson C.R., 1953. Estimation of variance and covariance components. Biometrics, 9, 226252. 
Hill W.G., Edwards M.R., Ahmed M.K.A., Thompson R., 1983. Heritability of milk yield and composition at different levels and variability of production. Anim. Prod., 36, 59-68.

HinkovSKI T.S., 1968. Value of some genetic determinants of milk production in semi-wooied sheep. I. Milk production and successive lactations (in Bulgarian). Genet. Selekts., 1, 371-380.

HoraK F., 1969. Heritability of ewes of udder measurements and milk yield and fat content. Zivocisna Vyroba, 14, 842-853.

Karras K., Scholte W., 1982. Ergebnisse von Populations Analysen für die Milchleistung in verschiedenen Laktationen beim Fleckvieh. Züchtungskunde, 54, 165-172.

Maisala K., Hanna M., 1974. Reliable phenotypic and genetic parameters in dairy cattle. 1st World Congress on Genetics Applied to Livestock Production, Madrid, October 7-11, 1974, vol. I, 541-563, Ed. Garsi, Madrid.

MaVrogenis A.P., 1982. Environmental and genetic factors influencing milk production and lambs output of Chios sheep. Livest. Prod. Sci., 8, 519-527.

MEYER K., 1984. Estimates of genetic parameters for milk and fat yield for the first three lactations in British Friesian cows. Anim. Prod., 38, 313-322.

MeYer K., 1985. Genetic parameters for dairy production of Australian Black and White cows. Livest. Prod. Sci., 12, 205-219.

Minev P., Katsarov Y., Dobrev D., Boshnakov I., 1971. Milk yield of local Stara Zagora ewes. Zhivotnovodstvo, 33, 90-92.

Ojeda Sahagun E., 1974. Raza ovina Manchega de Espana : repetibilidad y heredabilidad de su produccion lechera. 1st World Congress on Genetics Applied to Livestock Production, Madrid, October 7-11, 1974, vol. III, 1047-1051, Ed. Garsi, Madrid.

Pape H.C. Von, Claus J., Kalm E., 1983 a. Schätzung genetischer Parameter in aufeinanderfolgenden Laktationen beim Angler Rind in Schleswig-Holstein. I. Schätzung von Heritabilitäten. Züchtungskunde, 55, 14-23.

Pape H.C. Von, Claus J., Kalm E., 1983 b. Schätzung genetischer Parameter in aufeinanderfolgenden Laktationen beim Angler Rind in Schleswig-Holstein. II. Schätzung von korrelative Beziehungen. Züchtungskunde, 55, 24-33.

Poutous M., MocQuot J.C., 1975. Etudes sur la production laitière des bovins. III. Relation entre critères de production, durée de lactation et intervalle entre premier et deuxième vêlages. Ann. Génét. Sél. Anim., 7, 181-189.

Poutous M., Briend M., Calomiti S., Doan D., Felgines C., Steier G., 1981. Méthode de calcul des index laitiers. Bull. Tech. Inf., 361, 433-446.

RENDEl J.M., RoberTSON A., 1950. Estimation of genetic gain in milk yield by selection in a closed herd of dairy cattle. J. Genetics, 50, 1-7.

Robertson A., 1977. The effect of selection on the estimation of genetic parameters. Z. Tierz. Züchtungsbiol., 94, 131-135.

Romer J., Colleau J.J., Flamant J.C., 1971. Aspects quantitatifs de la production laitière des brebis. VIII. Variations des paramètres génétiques avec le niveau de production du troupeau et l'âge. Ann. Génét. Sél. Anim., 3, 331-335.

SCHNeEberger M., HAGger C., 1984. Genetic parameters for day open, milk yield, and fat and protein content of Swiss Braunvieh cows. Livest. Prod. Sci., 11, 261-268.

Soller M., Visoki M., Zamiri H., Sharav E., 1966. Heritability and repeatability of some selection criteria for milk production in Awassi (fat-tail) sheep. Israel J. Agric. Res., 16, 29-35.

Tecza S., 1969. Genetic and phenotypic correlations between wool yields, and staple length and milk yield in Polish Mountain sheep. Acta Agric. Silvest., 9, 119-127.

Tong A.K.W., Kennedy B.W., Moxley J.E., 1976. Effects of correcting for feeding levels on estimates of genetic parameters of milk yield and composition. Can. J. Anim. Sci., 56, 523-529.

VAN VLECK L.D., 1985. Including records of daughters of selected bulls in estimation of sire component of variance. J. Dairy Sci., 68, 2396-2402.

YARKIN I., Tuncel E., 1972. Genetische Parameter für Milch und andere Leistungen und die genetischen Verbesserungsmöglichkeiten beim Ivesischaf. Z. Tierz. Züchtungsbiol., 89, 199-216. 